\title{
Zinc Finger Protein 395
}

National Cancer Institute

\section{Source}

National Cancer Institute. Zinc Finger Protein 395. NCI Thesaurus. Code C117260.

Zinc finger protein 395 (513 aa, $55 \mathrm{kDa}$ ) is encoded by the human ZNF395 gene. This protein is involved in DNA binding. 